Review

\title{
Nursing profoundly premature newborns with artificial placentae: a review
}

\author{
Akinyemi Oyedele, Morakinyo Oyedele, Andrey V. Murashko \\ I.M. Sechenov First Moscow State Medical University, Moscow, Russian Federation
}

ABSTRACT

Neonatal mortality and morbidity are substantial issues affecting the maternal healthcare sector. Extremely premature infants, notably those born before the 28-week mark, experience significant morbidity and mortality rates during neonatal care. This is a result of developmental immaturity and iatrogenic injury. Several attempts have been made to develop a womb-like environment to mimic uteroplacental physiology, but limited success has been noted over the last decade. This review aims to summarize the current literature on improved techniques implemented in creating an artificial placenta, the principles of these procedures, and their limitations. Our findings indicate that implementing techniques that closely mimic uteroplacental pathophysiology is crucial in decreasing the excessive neonatal mortality and morbidity rates seen in extremely premature infants.

Keywords: placenta; neonatal; artificial placenta technology; neonatal mortality; premature infants.

To cite this article:

Oyedele A, Oyedele M, Murashko AV. Nursing profoundly premature newborns with artificial placentae: a review. V.F. Snegirev Archives of Obstetrics and Gynecology. 2021;8(4):185-190. doi: 10.17816/2313-8726-2021-8-4-185-190 
DOI: http://doi.org/10.17816/2313-8726-2021-8-4-185-190

Научный обзор

\title{
Выхаживание глубоко недоношенных новорождённых с помощью искусственной плаценты: 0бзор
}

\author{
A. Oyedele, M. Oyedele, A.B. Мурашко
}

Первый Московский государственный медицинский университет им. И.М. Сеченова (Сеченовский университет), Москва, Российская Федерация

\section{АННОТАЦИЯ}

Неонатальная смертность и заболеваемость - существенные проблемы, влияющие на охрану материнства. Недоношенные дети, особенно те, кто родился до 28-недельного срока, подвержены значительной заболеваемости и смертности в неонатальный период, что является результатом незрелости развития и ятрогенного повреждения. Предпринято несколько попыток создать маточную среду для имитации физиологии матки и плаценты, но за последнее десятилетие отмечены лишь ограниченные успехи. Данный обзор обобщает данные современной литературы по улучшенным методам, реализованным при создании искусственной плаценты, принципам этих процедур и их ограничениям. Наши результаты показывают, что внедрение методов, близко имитирующих физиологию внутриутробного развития, имеет решающее значение для снижения высокой неонатальной смертности и заболеваемости, наблюдаемых у экстремально недоношенных детей.

Ключевые слова: плацента; неонатальный; технология искусственной плаценты; неонатальная смертность; недоношенные дети.

\section{Как цитировать:}

Oyedele A., Oyedele М., Мурашко А.В. Выхаживание глубоко недоношенных новорождённых с помощью искусственной плаценты: обзор // Архив акушерства и гинекологии им. В.Ф. Снегирёва. 2021. Т. 8, № 4. С. 185-190. doi: 10.17816/2313-8726-2021-8-4-185-190 


\section{INTRODUCTION}

The placenta has an integral role in the neonatal delivery process of utero development in mammals due to its function in enhancing and supporting the development and maturation of the fertilized oocyte. Moreover, the placenta supports the development of the fetus by transferring nutrients and oxygen between the mother and the fetus (R. Tutar et al., 2021). However, despite the vast knowledge we have on the human placenta, it poses a significant challenge to research due to its short developmental processes and nine-month life span. Furthermore, the lack of feasibility of clinical testing in pregnant mothers, a result of both ethical and regulatory constraints, has subsequently resulted in the employment of animal models in artificial placenta (AP) research. Animal models carry their own limitations; however, concerning AP studies, animal models are not a true representation of the human placentation process. M. Aubuchon et al. attribute this lack of reproducibility to the variants of the human placentation process that differ from that of other species (M. Aubuchon et al., 2002; K. Orendi et al., 2011). To curb this limitation, U. Jammalamadaka et al. detail the combination of $3 \mathrm{D}$ printing technology and fetal stem cells as a viable approach to successfully creating APs (U. Jammalamadaka et al., 2018).

The current statistics establish that one in ten infants in the US is born premature (D.M. Ely et al., 2019). The World Health Organization estimated that in 2010 alone, 15 million infants were born preterm, at less than 37 weeks gestational age (GA), among which 780,000 were delivered extremely preterm (H. Blencow et al., 2010; WHO, 2012). In 1970, the neonatal mortality rate was 13.2 deaths per 1,000 live births, with this figure reducing to 3.3 deaths per 1,000 live births in 2019, according to the data released by the World Bank (The World Bank, 2019). Although these figures are attributable to numerous causes, placenta cord and membrane complications were among the top ten causes of infant mortality in Canada in 2018 after congenital malformations, chromosomal abnormalities, and deformations (D.B. Fell et al., 2020).

This review aims to evaluate the current literature regarding AP technology and the techniques involved in its creation. To achieve this, numerous objectives are to be executed: identify the scope of literature relevant to the aims of our review; extract the necessary data for analysis; compare findings between the literature; establish gaps in the literature that require future research.

\section{METHODOLOGY}

To obtain the scope of literature for analysis, a thorough search strategy was implemented to ensure all studies relevant to the aims of our review were identified. To achieve this, different keyword combinations were included in our search strategy. These keywords included and their corresponding Boolean operators are detailed below.
Keywords: artificial womb and/or placenta; prenatal or fetal; 3D printing in prenatal period; creating artificial placenta; extracorporeal and membrane oxygenation or membrane support.

The literature databases utilized were Embase, PubMed and Web of Science. These databases were chosen as they provided a thorough collation of the relevant articles specific to the objectives of this review, with the literature search being conducted in May 2021. Solely articles published in the English language were included in this review, with any literature published in a non-English language being excluded to prevent misinterpretation through translation. Gray literature was included and was yielded using Google Scholar.

\section{RESULTS}

Implementation of the search strategy yielded eleven articles relevant to the aims of this review various methods of reducing mortality and morbidity in extremely premature infants, including veno-venous extracorporeal life support programs, ex-vivo uterine environments, and arteriovenous extracorporeal life support programs. The data from the literature are compared and contrasted to identify key technologies and approaches in the creation of APs.

\section{Veno-venous preemies extracorporeal life support program (ECLS)}

Veno-venous preemies ECLS successfully experimented at the University of Michigan (USA), with the AP model being developed after the failure of the initial artificial womb (AW) model project. The ECLS was integrated with creating an AW model, using a pumpless AV circuit with fetal fluid submersion and umbilical vessel cannulation. The survival of the fetus in this device was limited to 4 hours despite adequate gas exchange. Fetal survival was hindered by the steady reduction in the systemic pressure $(55-35 \mathrm{~mm} \mathrm{Hg})$, oxygen delivery $(13.55-5.01 \mathrm{~mL} / \mathrm{kg} \times \mathrm{min})$, and sub-physiological flows $(72.49-33.40 \mathrm{~mL} / \mathrm{kg} \times \mathrm{min})$ within 4 hours, even with the use of fluid resuscitation and vasopressor. The study reported that the primary cause of circulatory and progressive cardiac failure was high cannula resistance (E.A. Partridge et al., 2017).

Neonatal ECLS was adapted and improved from an AW model to an AP model to aid oxygenation of fetuses with mechanical ventilation failure after birth. The model utilizes a pump-assisted veno-venous (VV) circuit with jugular vein/ umbilical vein (JV/UV) cannulation and a fluid-filled endotracheal tube as a surrogate for fluid immersion. According to the current literature on the AP model, vasopressors are required to stabilize hemodynamics, along with the administration of supraphysiological partial oxygen pressures to ensure adequate oxygenation. Inconsistent maintenance of ductal patency, despite the infusion of prostaglandin E1, was evident using this model. The average duration of fetal survival in the AP model presented in a study by B. Bryner 
et al. was extended from one day to just under two weeks (B. Bryner et al., 2015).

However, despite its evident benefits, this model has negative attributes of disencumbering cerebral oxygenation, blood flow and autoregulation in two-day long experiments. Mild small bowel epithelial injury was also observed during examination of the gastrointestinal tract, which may be attributable to vasopressor-induced splanchnic hypoperfusion, the absence of $A F$ ingestion, or a combination of both. The vasopressor and the use of the pump in the AP model demanded the assessment of cardiac function and structure, which is unreported to date (F.W. Bazer et al., 2012). There is also a need to scrutinize the model's results for reproducing smaller clinically equivalent fetal lambs compared to the studied fetal lambs, which corresponded to early and late saccular phases of lung development and mainly were around 118 or 130 days old. Also, the weight of the studied lambs $(2.5-5.1 \mathrm{~kg})$ was much higher than human fetal weights around the limits of viability $(0.5-0.7 \mathrm{~kg})$ (N.M. Talge et al., 2014).

\section{Ex vivo uterine environment (EVE)}

The ex vivo uterine environment (EVE) model, trialed by the Michigan group, was optimized via the collaboration of the Japanese Sendai team with the Australian team from Perth (H. Usuda et al., 2017). This model is additionally discussed in two individual studies, one conducted by J.L. Reoma et al. (J.L. Reoma et al., 2009), and another by Y. Miura et al. (Y. Miura et al., 2012). Both studies aimed to evaluate systemic and organ-specific inflammation in sheep models. The EVE protocol was improved by administering hydrocortisone to suppress inflammatory responses, stimulate lung maturation, and prevent hypocortisolemia refractory hypotension, similar to the Michigan group, which used a pumpless arteriovenous (AV) circuit. The inflammatory reaction was subdued with corticosteroids and the absence of infection. Analyzed brains showed evidence of white matter injury (WMI) due to either systemic hypoperfusion or acute embolic events, which calls for further optimization of the model in preparation for clinical translation. A supplementary study by $\mathrm{H}$. Usuda et al. aimed to assess the model on seven lambs, with the findings revealing that cannulated fetal lambs of 95 days' GA, weighing 0.6 to $0.7 \mathrm{~kg}$ (equivalent to 22 to 24 weeks' GA old human fetuses), were successfully sustained on pumpless AV circuit for five days, with stable hemodynamics, oxygenation, growth, and cardiac function (H. Usuda et al., 2019). The lungs and brains assessed were unremarkable, except for one sheep model that presented with evidence of WMI. This was most likely a result of the sheep experiencing a five-minute flow interruption due to accidental catheter occlusion. Recently, $\mathrm{H}$. Usuda et al. investigated the EVE's ability to support 95-day fetal lambs compromised by lipopolysaccharide-induced intrauterine inflammation, with this study noting that eight out of ten lambs survived five days on EVE. Three of the lambs had evidence of WMI on histology and six required dexamethasone to manage refractory hypotension (H. Usuda et al., 2020).

\section{Comparison between arteriovenous (AV) ECLS and veno-venous (VV) ECLS}

The AV-ECLS approach uses only the umbilical vessels for cannulation. Therefore, at the time of birth, an immediate transition of the infant to a fluid-filled artificial womb is required. This prevents umbilical vessel spasm and gas ventilation, while the VV-ECLS approach uses the umbilical vein and the internal jugular vein. After birth, the AV-ECLS technology is applied to infants failing maximal medical therapy or preemptively if risk-stratified for high mortality and morbidity (B. Fallon et al., 2020). Table provides an overview of the primary differences between AV and VV-ECLS AP systems in regard to the target population, cannulation, and airway management.

\section{Limitations}

Despite the achievements recorded in AP technology in the last ten years, some challenges still need to be addressed. A review conducted by F.R. De Bie et al. provides an overview of these challenges towards clinical translation, including reduction of oxygenator surface area, improvements to hemocompatibility of circuit components, and the

Table. Comparison between AV and VV-ECLS artificial placenta systems (B. Fallon et al., 2020)

Таблица. Сравнение артериально-венозной и вено-венозной систем экстракорпорального жизнеобеспечения с искусственной плацентой (B. Fallon et al., 2020)

\begin{tabular}{lcc}
\hline \multicolumn{1}{c|}{ Characteristic } & AV-ECLS & VV-ECLS \\
\hline Target population & EGA 22-24 weeks & EGA <28 weeks \\
Cannulation & During delivery & After failing ventilation \\
Draiage cannula & Umbilical artery (1 or 2) & Internal jugular vein \\
Reinfusion cannula & Umbilical vein & Umbilical vein \\
Circuit pump & Fetal heart & Mechanical pump \\
Airway management & Fluid-filled «biobag» & Intubated, fluid-filled lungs \\
\hline
\end{tabular}

$\mathrm{AV}$, arteriovenous; VV, veno-venous; ECLS, extracorporeal life support. 
mitigation of risk of germinal hemorrhage (F.R. De Bie et al., 2020). There is a need to improve the hemocompatibility of circuit components by finding a new biomaterial that will serve as a coating. This will aid in the elimination of the risk of germinal hemorrhage and the need for systemic anticoagulation. The decreasing pulsatile flow is another challenge to clinical translation that has been identified, highlighting the need to incorporate a closed complaint pressure chamber that will eliminate the UV from delivering pulsatile flows to the right heart of the fetal (F.R. De Bie et al., 2020).

\section{CONCLUSION}

Numerous AP technologies exist that function to reduce mortality and morbidity in extremely premature infants; however, there are still significant challenges that need to be overcome in order to reap the success of these approaches. These

\section{REFERENCES}

1. Aubuchon M, Schulz LC, Schust DJ. Preeclampsia: animal models for a human cure. Proc Natl Acad Sci USA. 2011;108(4):1197-1198. doi: 10.1073/pnas.1018164108

2. Bazer FW, Spencer TE, Thatcher WW. Growth and development of the ovine conceptus. J Anim Sci. 2012;90(1):159-170. doi: 10.2527/jas.2011-4180

3. Blencowe H, Cousens S, Oestergaard MZ, et al. National, regional, and worldwide estimates of preterm birth rates in 2010 with time trends since 1990 for selected countries: a systematic analysis and implications. Lancet. 2012;379(9832):2162-2172. doi: 10.1016/S0140-6736(12)60820-4

4. Bryner B, Gray B, Perkins E, et al. An extracorporeal artificial placenta supports extremely premature lambs for one week. J Pediatr Surg. 2015;50(1):44-49. doi: 10.1016/j.jpedsurg.2014.10.028

5. De Bie FR, Davey MG, Larson AC, Deprest J, Flake AW. Artificial placenta and womb technology: past, current, and future challenges towards clinical translation. Prenat Diagn. 2021;41(1):145-158. doi: 10.1002/pd.5821

6. Ely DM, Driscoll AK. Infant Mortality in the United States, 2017: Data From the Period Linked Birth/Infant Death File. Natl Vital Stat Rep. 2019;68(10):1+20.

7. Fallon B, Mychaliska $G$. Development of an artificial placenta for support of premature infants: a narrative review of the history, recent milestones, and future innovation. Transl Pediatr. 2020;10(5):1470+1485.

doi: $10.21037 / \mathrm{tp}-20-136$

8. Fell DB, Park AL, Sprague AE, et al. A new record linkage for assessing infant mortality rates in Ontario, Canada. Can J Public Health. 2020;111:278-285. doi: 10.17269/s41997-019-00265-6

9. Jammalamadaka U, Tappa K. Recent Advances in Biomaterials for 3D Printing and Tissue Engineering. Journal of Functional Biomaterials. 2018;9(1):22. doi: 10.3390/jfb9010022

10. Miura Y, Matsuda T, Funakubo A, et al. Novel modification of an artificial placenta: pumpless arteriovenous extracorporeal life support in a premature lamb model. Pediatr Res. 2012;72(5):490494. doi: 10.1038/pr.2012.108 challenges require improvement to oxygenator technology, sterility, circuit configuration, vascular access, nutrition, fluid submersion, and medical management as these features are crucial in mimicking the uteroplacental physiology.

\section{ADDITIONAL INFO}

Author contribution. All authors made a substantial contribution to the conception of the work, acquisition, analysis, interpretation of data for the work, drafting and revising the work, final approval of the version to be published and agree to be accountable for all aspects of the work.

Funding source. This study was not supported by any external sources of funding.

Competing interests. The authors declares that there are no obvious and potential conflicts of interest associated with the publication of this article.

11. Orendi K, Kivity V, Sammar M, et al. Placental and trophoblastic in vitro models to study preventive and therapeutic agents for preeclampsia. Placenta. 2011;32 Suppl.:S49-54. doi: 10.1016/j.placenta.2010.11.023

12. Partridge EA, Davey MG, Hornick MA, Flake AW. An EX Trauterine environment for neonatal development: EXTENDING fetal physiology beyond the womb. Semin Fetal Neonatal Med. 2017;22(6):404-409. doi: 10.1016/j.siny.2017.04.006

13. Reoma JL, Rojas A, Kim AC, et al. Development of an artificial placenta I: pumpless arterio-venous extracorporeal life support in a neonatal sheep model. J Pediatr Surg. 2009;44(1):53-59. doi: 10.1016/j.jpedsurg.2008.10.009

14. Talge NM, Mudd LM, Sikorskii A, Basso 0. United States birth weight reference corrected for implausible gestational age estimates. Pediatrics. 2014;133(5):844-853. doi: 10.1542/peds.2013-3285

15. The World Bank. Mortality Rate, Infant (per 1,000 live births). 2019. Retrieved from https://data.worldbank.org/indicator/ SP.DYN.IMRT.IN

16. Tutar R, Çelebi-Saltik B. Modelling of Artificial 3D Human Placenta. Cells tissues organs. 2021;1-10. Advance online publication. doi: 10.1159/000511571

17. Usuda H, Watanabe S, Miura Y, et al. Successful maintenance of key physiological parameters in preterm lambs treated with ex vivo uterine environment therapy for one week. Am J Obstet Gynecol. 2017;217(4):457.e1-457.e13. doi: 10.1016/j.ajog.2017.05.046

18. Usuda $H$, Watanabe $S$, Saito $M$, et al. Successful use of an artificial placenta-based life support system to treat extremely preterm ovine fetuses compromised by intrauterine inflammation. $\mathrm{Am} \mathrm{J}$ Obstet Gynecol. 2020;223(5):755.e1-755.e20.

doi: 10.1016/j. ajog.2020.04.036

19. Usuda H, Watanabe $S$, Saito $M$, et al. Successful use of an artificial placenta to support extremely preterm ovine fetuses at the border of viability. Am J Obstet Gynecol. 2019;221(1):69. e1-69.e17. doi: 10.1016/j.ajog.2019.03.001

20. World Health Organization and Partners. Born too soon: The global action report on preterm birth. 2012. https://www.who. int/pmnch/media/news/2012/201204_borntoosoon-report.pdf 


\section{СПИСОК ЛИТЕРАТУРЫ}

1. Aubuchon M., Schulz L.C., Schust D.J. Preeclampsia: animal models for a human cure // Proc Natl Acad Sci USA. 2011. Vol. 108, N 4. P. 1197-1198. doi: 10.1073/pnas. 1018164108

2. Bazer F.W., Spencer T.E., Thatcher W.W. Growth and development of the ovine conceptus // J Anim Sci. 2012. Vol. 90, N 1. P. 159170. doi: $10.2527 /$ jas.2011-4180

3. Blencowe H., Cousens S., Oestergaard M.Z., et al. National, regional, and worldwide estimates of preterm birth rates in 2010 with time trends since 1990 for selected countries: a systematic analysis and implications // Lancet. 2012. Vol. 379, N 9832. P. 2162-2172. doi: 10.1016/S0140-6736(12)60820-4

4. Bryner B., Gray B., Perkins E., et al. An extracorporeal artificial placenta supports extremely premature lambs for one week // J Pediatr Surg. 2015. Vol. 50, N 1. P. 44-49. doi: 10.1016/j.jpedsurg.2014.10.028

5. De Bie FR, Davey M.G., Larson A.C., Deprest J., Flake A.W. Artificial placenta and womb technology: past, current, and future challenges towards clinical translation // Prenat Diagn. 2021. Vol. 41, N 1. P. 145-158. doi: 10.1002/pd.5821

6. Ely D.M., Driscoll A.K. Infant Mortality in the United States, 2017: Data From the Period Linked Birth/Infant Death File // Natl Vital Stat Rep. 2019. Vol. 68, N 10. P. 1-20.

7. Fallon B., Mychaliska G. Development of an artificial placenta for support of premature infants: a narrative review of the history, recent milestones, and future innovation // Transl Pediatr. 2020. Vol. 10, N 5. P. 1470-1485. doi: 10.21037/tp-20-136

8. Fell D.B., Park A.L., Sprague A.E., et al. A new record linkage for assessing infant mortality rates in Ontario, Canada // Can J Public Health. 2020. Vol. 111. P. 278-285.

doi: 10.17269/s41997-019-00265-6

9. Jammalamadaka U., Tappa K. Recent Advances in Biomaterials for 3D Printing and Tissue Engineering // Journal of Functional Biomaterials. 2018. Vol. 9, N 1. P. 22. doi: 10.3390/jfb9010022

10. Miura Y., Matsuda T., Funakubo A., et al. Novel modification of an artificial placenta: pumpless arteriovenous extracorporeal life support in a premature lamb model // Pediatr Res. 2012. Vol. 72, N 5. P. 490-494. doi: 10.1038/pr.2012.108

\section{AUTHORS INFO}

*Andrey V. Murashko, M.D., Dr. Sci. (Med.), professor; address: 119991, Moscow, Russian Federation,

8-2 Trubetskaya str.; ORCID ID: 0000-0003-0663-2909, SPIN-kod: 2841-9638;

e-mail:murashkoa@mail.ru

Akinyemi Oyedele, MD; resident of the 2nd year of study; ORCID ID: 0000-0001-7429-6834;

e-mail: akinyo11@gmail.com

Morakinyo Oyedele, MD; resident of the 2nd year of study; ORCID ID: 0000-0002-2093-4754;

e-mail: morakinyo.oyedele@hotmail.com
11. Orendi K., Kivity V., Sammar M., et al. Placental and trophoblastic in vitro models to study preventive and therapeutic agents for preeclampsia // Placenta. 2011. Vol. 32, Suppl. P. S49-54. doi: 10.1016/j.placenta.2010.11.023

12. Partridge E.A., Davey M.G., Hornick M.A., Flake A.W. An EX Trauterine environment for neonatal development: EXTENDING fetal physiology beyond the womb // Semin Fetal Neonatal Med. 2017. Vol. 22, N 6. P. 404-409. doi: 10.1016/j.siny.2017.04.006

13. Reoma J.L., Rojas A., Kim A.C., et al. Development of an artificial placenta I: pumpless arterio-venous extracorporeal life support in a neonatal sheep model // J Pediatr Surg. 2009. Vol. 44, N 1. P. 53-59. doi: 10.1016/j.jpedsurg.2008.10.009

14. Talge N.M., Mudd L.M., Sikorskii A, Basso O. United States birth weight reference corrected for implausible gestational age estimates // Pediatrics. 2014. Vol. 133, N 5. P. 844-853. doi: 10.1542/peds.2013-3285

15. The World Bank. Mortality Rate, Infant (per 1,000 live births). 2019. Retrieved from https://data.worldbank.org/indicator/ SP.DYN.IMRT.IN

16. Tutar R., Çelebi-Saltik B. Modelling of Artificial 3D Human Placenta // Cells tissues organs. 2021. P. 1-10. Advance online publication. doi: 10.1159/000511571

17. Usuda H., Watanabe S., Miura Y., et al. Successful maintenance of key physiological parameters in preterm lambs treated with ex vivo uterine environment therapy for one week // Am J Obstet Gynecol. 2017. Vol. 217, N 4. P. 457.e1-457.e13. doi: 10.1016/j.ajog.2017.05.046

18. Usuda H., Watanabe S., Saito M., et al. Successful use of an artificial placenta-based life support system to treat extremely preterm ovine fetuses compromised by intrauterine inflammation // Am J Obstet Gynecol. 2020. Vol. 223, N 5. P. 755. e1-755.e20. doi: 10.1016/j. ajog.2020.04.036

19. Usuda H., Watanabe S., Saito M., et al. Successful use of an artificial placenta to support extremely preterm ovine fetuses at the border of viability // Am J Obstet Gynecol. 2019. Vol. 221, N 1. P. 69.e1-69.e17. doi: 10.1016/j.ajog.2019.03.001

20. World Health Organization and partners. Born too soon: The global action report on preterm birth. 2012. https://www.who. int/pmnch/media/news/2012/201204_borntoosoon-report.pdf

\section{ОБ АВTOPAX}

*Мурашко Андрей Владимирович, Д.М.Н., профессор; адрес: 119991, г. Москва, Россия, ул. Трубецкая, д. 8, стр. 2; ORCID ID: 0000-0003-0663-2909, SPIN-код: 2841-9638; e-mail:murashkoa@mail.ru

Akinyemi Oyedele, MD; ординатор 2-го года обучения; ORCID ID: 0000-0001-7429-6834; e-mail: akinyo11@gmail.com

Morakinyo Oyedele, MD; ординатор 2-го года обучения; ORCID ID: 0000-0002-2093-4754;

e-mail: morakinyo.oyedele@hotmail.com 